\title{
Is Cane Sugar Production for Biofuel a Good Practice in Semi-Arid Systems? A Special Reference to the Olifants River Catchment, Mpumalanga, South Africa
}

\author{
Thomas K. Gyedu-Ababio ${ }^{1 *}$, F. Venter ${ }^{2}$ \\ ${ }^{1}$ South African National Parks (Kruger National Park), Phalaborwa, South Africa \\ ${ }^{2}$ South African National Parks (Kruger National Park), Skukuza, South Africa \\ Email: *thomas.gyedu-ababio@sanparks.org
}

Received December 18, 2012; revised January 20, 2013; accepted January 31, 2013

\begin{abstract}
The aim of this paper is to analyse the possible impacts of proposed biofuel production at Hoedspruit in the Olifants River Catchment. These impacts are looked at in terms of availability of water and subsequent consequences on downstream users, especially the Kruger National Park that is mandated to conserve and protect biodiversity in all facets and fluxes in its area of jurisdiction. Based upon a review of experiences with biofuel production and impacts around the world, water availability for sugar cane production to support proposed biofuel production was found to be a problem in the region that has an average rainfall of only $450 \mathrm{~mm}$ per annum. The Olifants River system already has a deficit of about 200 million $\mathrm{m}^{3} / \mathrm{a}$; hence the sustainability of the sugar cane based biofuel industry in the proposed area is questioned in this review. It is advised that alternative plants for the production of biofuel that may not consume large quantities of water be examined.
\end{abstract}

Keywords: Land Use; Energy Alternatives; Sugar Cane; Sustainable Development; Water Availability; Biodiversity

\section{Introduction}

Global interest in biofuels has been driven by support for and increasing acceptance of the need for renewable energy sources and growing concern for the environment including climate change [1]. The use of fossil fuels has contributed to global warming and associated climatic changes [2]. The use of alternative energy sources such as biofuels, is being explored. [3] has hinted that the sugar industry in close collaboration with the government of South Africa is exploring legislative options which will accommodate the production of ethanol-based biofuel from sugar cane both within and outside the existing structure of the South African Sugar Industry. The draft biofuels plan [1] approved by the South African government is expected to produce 75 percent of the country's renewable energy target (over a billion litres of biofuels by 2013), in compliance with the Kyoto Protocol on climate change. The capital investment required would be about R6bn. The objectives of the Biofuel strategy are: to contribute to the country's development goals, to the renewable energy target, to generate employment and to the reduction of the negative impact of energy consumption on the environment [1].

"Corresponding author.
There are other international reports including [4] which argue that recent advances in knowledge mean that plantderived biofuels could meet about $30 \%$ of the global demand for liquid transportation fuels, drastically reducing the amounts of greenhouse gases released into the atmosphere from burning fossil fuels, without having an impact on food production.

In their article, [4] argue that advances in the technology used to produce and extract plant biomass to be burned directly or converted to liquid fuels may allow the expansion of productivity to a scale large enough to meet the demand for an estimated $30 \%$ of all liquid transportation fuels. This sort of expansion will depend on the availability of land and water. In areas where such an expansion will depend on rain-fed water, production will be sustainable. In South Africa and in the Hoedspruit area of the Olifants Catchment, the possibility of rain-fed cane sugar production is zero. Water in the Olifants systems is overdeveloped and in a deficit in terms of supply to water users. The expansion of biofuel production is a topic with complex economic, ecological, environmental and political concerns.

It is an accepted fact that irrigated agriculture accounts for $70 \%$ of global water withdrawals and therefore contributes substantially to global water scarcity. Based on 
biofuel production projections for 2008 and 2017, it was estimated that currently around $1 \%$ of all water withdrawn for irrigation is used for the production of bioethanol, mainly produced from irrigated sugar cane and maize [5]. [5] purport that in 2017 the amount of water to be withdrawn for biofuel production would increase by $74 \%$ if agricultural practices remain the same. Even though globally the amount of water withdrawn for the production of biofuels is modest, locally water scarcity problems may worsen due to irrigation of bio-ethanol feedstocks. In this context there is reason for concern in countries with fast-developing economies like India, China, Thailand and South Africa where the growing demand for food and energy causes an increased competition for already scarce water resources [5]. This situation will be aggravated if the projected bio-ethanol production will come from irrigated sugar cane.

This manuscript highlights concerns about unsustainable production of biofuel from cane sugar in a catchment that is already in a deficit (demand for water exceeds the supply). The objective of this paper is to bring to the attention of readers and authorities that although biofuel has some positive environmental impacts, its production should not be done in just every catchment and that the feedstock for such production should be investigated thoroughly in relation to the catchments in which such production will be made.

\section{Study Area}

An area in the Olifants River Catchment (Hoedspruit region) has been earmarked by some farmers for the growing of sugar cane to produce biofuel (Figure 1). The specific sites are located in the Olifants River Primary Catchment (B). Locally, it is drained by two quaternary catchment areas, $\mathrm{B} 71 \mathrm{H}$ and B60J. Surface water from the two sites drains northwest towards the Olifants River in the $\mathrm{B} 71 \mathrm{H}$ catchment; and east towards the Blyde River in the B60J quaternary catchment [6]. The area earmarked for the production of cane sugar falls within the region which receives an average annual rainfall of $\pm 500 \mathrm{~mm}$. This implies that, the sugar produced in this catchment will be irrigation dependent. The Olifants River catchment is currently in a deficit of 192 million $\mathrm{m}^{3} / \mathrm{a}$ [7]. This means that the current demand is greater than the supply in the Olifants River catchment. The sugar cane production to support biofuel production in the catchment might increase the deficit which is expected to increase to 241 million $\mathrm{m}^{3} / \mathrm{a}$ by 2025 [7]. This will be as a result of changing from less thirstier plants to a thirstier crop, cane sugar. According to the ISP, the water resources in the Olifants are substantially regulated and are almost fully developed.

The Olifants River drains through the Kruger National Park (KNP), which is a major contributor to the South
African economy, before emptying into the sea via Mozambique. The KNP needs water to maintain the biodiversity in the park. Mozambique also needs the water for their economic development. The raising of the Massingir Dam wall in the Olifants River catchment in Mozambique attests to this fact.

Currently, impacts on this Olifants River upstream and adjacent to the Kruger National Park have resulted to low flow, pollution and high silt levels in the river [8-11] and loss of many riverine species of macro-invertebrates and fish that are dependant on flowing water as a habitat. Flow stoppages in the Olifants River have caused massive fish kills $[10,11]$ and the extirpation of one sensitive fish specie Opsaridium peringueyi [10]. Many more species might be lost if the flow in the Olifants is further limited. The specialist water assessment report for the project in question indicates that the ground water in the area is vulnerable to pollution. The aquifer can be divided into zones with differences in hydraulic properties and hence vulnerable to contamination. The aquifer vulnerability for all the aquifers was qualitatively evaluated using the parameters as set out in the DRASTIC method [6]. The quaternary deposit is a major, unconfined aquifer that will be vulnerable to pollution due to a shallower depth to groundwater, higher recharge, porous aquifer media, flatter topography and higher hydraulic conductivity [6].

\section{Methods}

Since the production of crops for biofuels is relatively new in South Africa, various publications and literature reviews on the subject were sought globally to compare the lessons learned in various countries where biofuels from sugar cane have been produced. The water balance in the Olifants River Water Management Area (WMA) was reviewed. The Kruger National Park's experiences with both the quantity and quality of water in the Olifants River were recounted and applied to the proposed Hoedspruit experience with biofuels crop production which has yet to be implemented although the Record of Decision (ROD) for the establishment of the ethanol plant has been given by the Limpopo Provincial Government.

\section{Discussion}

\subsection{Water as a Limited Resource}

The depletion of water supplies is a global challenge to biodiversity, and biofuel production has contributed to additional agricultural water consumption [12]. The growing, harvesting and processing of crops for biofuel in most cases withdraw considerable quantities of water. It has been stated that the water used in corn-based ethanol refineries in the US is about four litres of water for every litre of ethanol produced [13]. According to the 


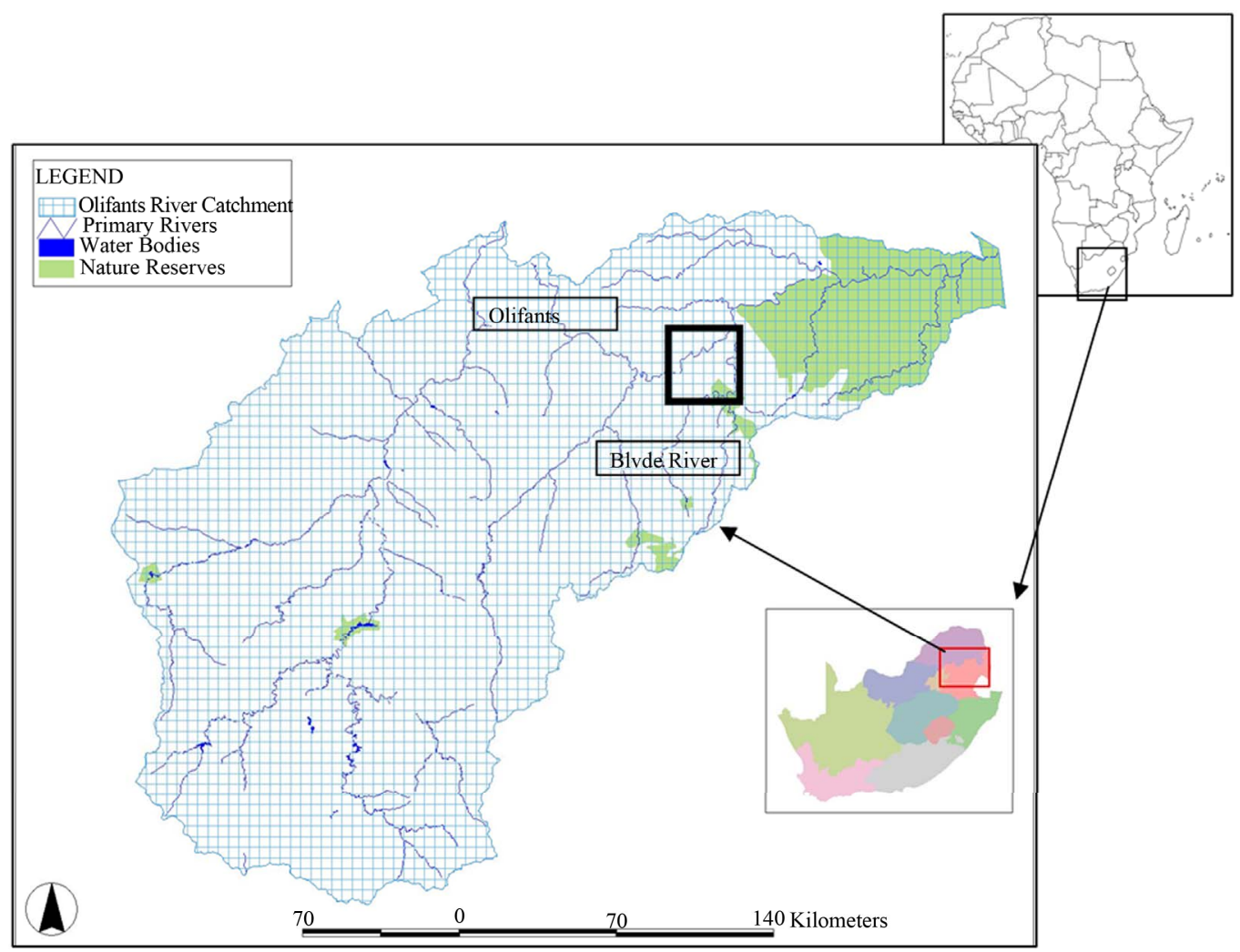

Figure 1. Indication of the location of the biofuel project.

same source, data on water required for the various feedstocks indicate that sugar cane consumes large quantities of water (see Table 1). [14] says growing biomass needs between 1000 - 3500 litres of water for the production of 1 litre of biofuel.

Water is a vital resource for South Africa's future prosperity. Its sustainable use within an integrated natural resources management framework for economic, social and environmental gains underpins planning and operational activities in the government, industry and community sectors. [15] rightly noted that "the growth and production of biodiesel/biofuel crops in high rainfall areas will impact on other water resource users and could only be permitted where water was available. Water is a critical limiting factor and many of South Africa's catchments are closed to further development requiring water. This applies particularly to irrigated agriculture and forestry. Water could be traded out with other licensed users, and typically one might find forestry being exchanged for biodiesel cropping should the economics be favourable. This is the "first economy" option, recognised by the Department of Minerals and Energy (DME), and would greatly reduce the net gain offered through biodiesel/biofuel production. The extensive planting of any crop which increases the biomass of the vegetation cover is likely to use more water. This can affect streams, rivers, and groundwater supplies [15].
The water specialist assessment report of the proposed project has indicated that, the average make-up water use would be $1800 \mathrm{~m}^{3} / \mathrm{d}$ for both process and potable water requirements. The potable component would be $200 \mathrm{~m}^{3} / \mathrm{d}$ and the average make-up water use (i.e. consumption) would be in the order of $0.35 \mathrm{~m}^{3} /$ ton; the make-up water component from the residual water at the sugar mill is calculated at $3000 \mathrm{~m}^{3} / \mathrm{d}$ [16]. This water would be settled in the waste water dams and re-used in the process plant; and the make-up water requirements of $1800 \mathrm{~m}^{3} / \mathrm{d}(21 \mathrm{l} / \mathrm{s})$ would be obtained from the irrigation pipeline that runs past the south-western corner of the farm Richmond. This pipeline has a total capacity of 8000 ha $(95 \mathrm{l} / \mathrm{s})$. The water would be obtained by buying water rights from willing sellers and converting to industrial water use. The make-up water requirement of $1800 \mathrm{~m}^{3} / \mathrm{d}(21 \mathrm{\ell} / \mathrm{s})$ would be represented by 30 ha to 40 ha irrigation area.

The amount of water that is purported for trading is from farmers who used the water for irrigation in the past but for Mango and citrus. Citrus and mango do not require the amount of water that cane sugar will need. Another question that needs to be answered is will the water supplemented from the game farms be sufficient enough for both the feedstock farming and the processing plant? Changes in land use may alter the amount of food being produced for local markets, and so might reduce food availability. Threats to biodiversity and loss of environ- 
Table 1. Feedstock water consumption and biofuel yield.

\begin{tabular}{ccc}
\hline Feedstock & $\begin{array}{c}\text { Feedstock water } \\
\text { consumption } \\
\text { (irrigated litre } \\
\text { water/litre fuel) }\end{array}$ & $\begin{array}{c}\text { Biofuel yield } \\
\text { litres of fuel/ha }\end{array}$ \\
\hline Corn & 3709.3 & 1514 \\
Sorghum & 7191.5 & 643.45 \\
Sugar Beet & 4163.5 & 2119.6 \\
Sugar Cane & 5147.6 & 2081.75 \\
\hline
\end{tabular}

mental services constitute another concern. Large commercial deals typically involve the transition from multiple land uses, intercropping and low-level use of forest products to forest clearance and monocropping.

The water specialist assessment report on the project indicates that there will be no impact on the groundwater quantity as groundwater will not be used as a source of water supply. But, the report does not indicate the relationship between the surface and ground water as impacts on the ground water can affect the base flow in the rivers and vice versa. "The Blyde River irrigation scheme has a capacity of 8000 ha. The plant will use the same volume of water allocated to 30 - 40 ha and would be obtained from irrigation rights that are not in use any more (due to changes of farming method from e.g. irrigation to game)" [6]. Where will the water for the feedstock come from? The agricultural assessment done for the pre-feasibility study concluded that the climate in the area of a $65 \mathrm{~km}$ radius from the proposed plant site is suitable for sugar cane growing. A radius of $65 \mathrm{~km}$ from the Ethanol Plant was used for the assessment as it forms the economic limit from where product can be transported to the plant. The rainfall ranges between $400 \mathrm{~mm}$ to $600 \mathrm{~mm}$ per year and the supplementary water of 1100 $\mathrm{mm} / \mathrm{a}$ (totalling $1500-1700 \mathrm{~mm} / \mathrm{a}$ ) would be obtained from the irrigation schemes in the feedstock area [16].

The irrigation areas for the feedstock sources are located in the Olifants River primary catchment (B). This catchment is classified by the Department of Water Affairs and Forestry (DWAF) as stressed and no additional water is available for the expansion of irrigation areas. The only water that is available is from Hoedspruit Ethanol Plant. According to the water specialist assessment report, existing lawful use could be obtained by transforming existing irrigation areas with existing water allocations from e.g. mango and citrus to sugar cane and sweet sorghum. To determine the feasibility of planting sugar cane and sweet sorghum instead of citrus and mango, the water uses were compared. According to Dr. P. Scholtz (personal communication), member and former chairman of the Blyde River Irrigation Board, citrus and mango uses $9900 \mathrm{~m}^{3} / \mathrm{ha} /$ year and sugar cane and sweet sorghum use $11,000 \mathrm{~m}^{3} / \mathrm{ha} /$ year. The sugar cane and sweet sorghum water use in terms of the yield planned for in this project is therefore $11 \%$ higher than the current water use based on citrus and mango. This means that $11 \%$ less area would be available based on the higher water use, which leaves 30,600 ha of irrigation land available for sugar cane and sweet sorghum based on the higher water use. The DWAF indicated that due to the stressed nature of the Olifants Catchment, compulsory licensing will be implemented in the near future (DWAFAGES Meeting). The DWAF will do an in depth investigation during the compulsory licensing process to determine the availability of water in the Olifants Catchment (B).

"The Reserve is that portion of the natural flow that has to be available in a river or stream in order to sustain the aquatic ecology or environmental water requirements (EWR), and also to provide for basic human needs, in order to comply with Sections 16, 17 and 18 of the South African National Water Act (NWA), Act 36 of 1998. The Reserve is not a steady flow, but is a variable flow that mimics natural variations in flows in the river. The quantity that is required takes into account 'normal' conditions, as well as drought conditions. Provision has therefore only been made for that portion of the Reserve that is practically implementable. This will reduce the available yield of the whole system by 157 million $\mathrm{m}^{3} / \mathrm{a}$ in order to maintain the ecological categories at their recommended levels. The full Reserve with the flood component would have reduced the available yield by 221 million $\mathrm{m}^{3} / \mathrm{a}$ " [17].

The outcome of the recently completed reconciliation study includes a reduction in the water allocations with a consequent reduction in irrigation land with the availability of water as the constraint. The impact on the aquatic biodiversity will be worse. Currently, the Environmental Water Requirements (EWR) as indicated in the National Water Act (36 of 1998) is not fully implemented in the Olifants Catchment and the likelihood of the current situation deteriorating is imminent if such a project goes ahead. The above concerns will definitely have an impact on the management of biodiversity in the Kruger National Park which depends on water from the affected catchment.

\subsection{Land Use Impacts}

[18] reported that the Industrial Development Corporation (IDC) has announced that greener fuel will finally come to South Africa as R5.1 billion will be made available to develop liquid biofuels. The money will be used to support the production of 300 million litres of greener fuels every year from 2016 onwards. The project will explore feedstock such as maize, sugar cane, sorghum, soya beans and algae for fuel generation which includes bioethanol and biodiesel. According to the same source, 
it has been estimated by the sugar companies that replacing only $10 \%$ of the country's liquid fuel supply with sugar-based bioethanol could create 110,000 jobs in the industry.

However, as indicated earlier in this review, existing uses in the study area are for high-value cropping - mangoes, oranges, avocados and the like. Sugar is a lowvalue crop, it generally uses MORE water than the abovementioned crops, and most certainly it takes less people to grow, manage, and market. It feeds fewer people too. To say that there will be job creation benefit where change of land use as indicated in this review is concerned is to repeat the gross misrepresentation of the facts by the project proponents. Jobs will be lost in this type of land use change and other livelihoods would also be lost. Land use changes such as those associated with extensive crop establishment of this nature can result in disturbance to flow patterns and damage to riparian zones and wetlands. According to [19] position statement, environmental degradation through biofuel production in the UK, Europe and globally may occur (and is already occurring in some parts of the world) through; 1) land use changes to accommodate energy crop plantations which result in loss, fragmentation and degradation of valuable habitats (especially grasslands, forests, wetlands and extensive agricultural areas) and negative impacts on associated biodiversity and ecosystem services; 2) intensification of agricultural production, i.e. increased use of agro-chemicals and water resources which leads to biodiversity loss, water shortages, increased water pollution and eutrophication, and soil degradation and erosion; 3) the release of carbon from natural carbon sinks, such as peatlands and forests, through land use changes, negating any carbon savings made through the use of biofuels whilst at the same time increasing overall global greenhouse gas emissions; 4) displaced food production encroaching on valuable habitats (land leakage); and 5) the unregulated use of genetically modified feed stocks (outside the EU), which may be damaging to wildlife, competitively displace native species or lead to gene flow with native species.

Increased biofuel production, especially based on conventional annual crops, may result in higher rates of soil erosion, nutrient leaching and biodiversity loss owing to the increased need for tillage [20]. In view of these concerns, at a meeting of the Mpumalanga Cane Growers Association (MpCGA) reported that the production of ethanol from sugar cane was currently not economically viable. The MpCGA insist that the Hoedspruit project would require about 20,000 ha (including feedstock production) to ensure sustainability and doubted whether there was adequate water in the Blyde River system to sustain sugar cane. It was further noted that although sugar cane was considered the best plant to use for etha- nol production, there were doubts as to whether the natural environmental resources of Hoedspruit could sustain it without negative impacts on the biodiversity of the Kruger National Park (which is downstream).

\subsection{Managing Biodiversity}

The importance of water and related aquatic biodiversity can not be overemphasized. Although, the environment is recognized as a legitimate user of water in the National Water Act, South Africa, implementation of the reserve is yet to be realised in the Olifants system. This provision covers both surface and groundwater dependent ecosystems, streams, lakes, wetlands and springs. Providing water for the environment is necessary to ensure ecosystem integrity, productivity and long term sustainability. Healthy water dependent ecosystems contribute to the health of the water resources that sustain our industries and the community's economic, social and environmental values. The introduction of "alien species" for biofuel production may, result in the clogging of streams and rivers and other habitats in unintended ways, to the detriment of both water resources and biodiversity.

Urban and agricultural development has traditionally been seen as primary drivers of encroachment on important, biodiversity-sustaining ecosystems. But, according to [21], the use of plant biomass to provide liquid fuels, is exacerbating agriculture's impact on biodiversity. The most significant biodiversity threat is the potential for biofuel feedstock production to extend agriculture's encroachment on native vegetation. "The current massive degradation of habitat and extinction of species is taking place on a catastrophically short timescale, and their effects will fundamentally reset the future evolution of the planet's biota" [22]. When humans manage an ecosystem for the purpose of food, fiber and fuel production, they often limit the biodiversity of that land area. The degree to which they limit biodiversity depends upon the type of agriculture that is practiced. In Brazil, deforestation and its impact on biodiversity has been one of the primary results of the biofuel boom in that country. The country's Atlantic Rainforest (Mata Atlantica) once covered more than $800,000 \mathrm{~km}^{2}$, but today only about seven percent remains [23] and much of that is severely fragmented [24].

The quantity and quality of water in the Olifants River is continuously deteriorating [11] to the detriment of the biodiversity and this is making it difficult for the Kruger National Park to achieve its mission/vision [10]. It is believed that this is primarily the result of dam management, river abstractions and discharges from the mines and industries. The Kruger National Park fears that implementation of the sugar cane plantation for biofuel production in the Olifants River Catchment will make matters worse for the management and or the protection 
of biodiversity in the Olifants River Catchment.

\subsection{Any Alternatives to the Use of Sugar Cane as Biofuel Plant?}

Woody biomass can be harvested sustainably for lumber and paper and may, therefore, provide biofuel feedstock for some regions [25]. By one estimate, the biomass that is harvested annually in the Northern Hemisphere for wood products has an energy content equivalent to approximately $107 \%$ of the liquid fuel consumption in the United States of America (US) [26].

Foremost among feedstocks are jatropha, palm oil, maize and soya for biodiesel and sugar cane for bioethanol. [27] indicates that biofuels reduce greenhouse-gas emissions in comparison to fossil fuels. But, Smithsonian researchers highlight a new study that factors in environmental costs of biofuel production [27]. Corn, soy and sugarcane come up short. The authors urge governments to be far more selective about which biofuels they support, as not all are more environmentally friendly than fossil fuels.

According to [28], "the alien invasive Nypa palm (Nypa fruticans) which has invaded and colonized over $200 \mathrm{~km}^{2}$ of the Atlantic coast around Nigeria have been proven to produce a far greater bio-fuel crop per hectare than sugar cane; yet it is regarded as one of the greatest environmental problems facing Nigerian coastal areas because the interests and capacity to produce bio-fuels or make other substantial use of the plant is currently lacking. Other invasive species like Lantana camara in eastern Africa, Water hyacinth (Eichornia crassipes) in most tropical waters can be converted into bio-fuels without undue stress on human foods". These alien plants do not need volumes of water for their growth [28]. [28] adds that industrial forest plantations covering millions of hectares across the world; e.g. Gmelina (Gmelina arborea) yield enormous amounts of seeds per hectare per season that can be collected and processed into bio-fuels, aside from possible use of crop residues as well as biogas from animal and human wastes to supplement our energy needs.

\section{Conclusion}

There is great potential for the effective introduction of biofuel to South Africa [29]. There are clearly good long-term prospects, though policy-makers must first be informed of the practical requirements, the potential for an affordable energy supply, and the barriers that will need to be overcome. International experience in this regard is a vital issue and should be carefully considered to avoid committing resources for the support of an illconceived approach. "The crop prices needed to establish a $10 \%$ biofuels industry in South Africa are unsustain- able and in general are below production costs. Although oil companies are supportive of biofuels blending, the economics do not suggest a large, sustainable biofuels industry is possible in South Africa under the current dispensation [30]."

South Africa's population is growing and with the influx of people from neighbouring countries, we will need to increase our food production. On a global scale Johan Kuylenstierna, director of World Water Week 2007 says "food production will need to increase, water consumption will increase dramatically in the agriculture sector and biofuels will increase. This doesn't add up for the water perspective". It should also be emphasised that bioenergy could, compared to fossil fuels drastically reduce green house gas emissions if managed appropriately. Bioenergy also offers significant opportunities to improve sustainable development, especially in smaller scale rural areas, as underlined by the examples given in [31] for India, and by [32] for Tanzania. It should be noted, however, that research on sustainable bioenergy systems in South Africa is a very young science, so that few studies and empirical, field-derived data are not available as yet. This applies even more to sustainability issues of bioenergy in developing countries, e.g. South Africa, where semi-arid, arid and tropical climates restrict the application of results from "Northern" countries, which have different soils and climates and use different farming systems.

In this regard, China, a developing country has a word of caution for all developing countries venturing into biofuel production. According to [33], developing countries face different situations than do developed countries. They must address the food security issue when they develop biofuels. We as authors of this paper will want to add our voice to the debate by advising the proponents of the sugar cane venture in the Olifants River catchment in South Africa or in other semi-arid catchments to carefully analyse all the critical issues associated with water in the catchment(s) before the project is initiated. Any such project should be undertaken with a view toward the long term and the practice of sustainability.

It can be concluded that biofuel production in South Africa would be a reasonable option only if; critical irrigation needs in semi dry and dry regions like the Olifants River Catchment can be avoided and, alternative crops that have little impact on the biodiversity with reference to water requirements are considered. As it stands, sugar cane production in the Hoedspruit region of the Olifants Catchment might not be a good idea.

\section{Acknowledgements}

We thank our colleagues from the Kruger National Park, especially, Harry Biggs and Stefanie Freitag-Scott who provided us literature on biofuels from different sources. 


\section{REFERENCES}

[1] Department of Minerals and Energy (DME), "Draft Biofuels Industrial Strategy of the Republic of South Africa," 2006.

http://www.compete-bioafrica.net/policy/Biofuels_Strategy_ SA.pdf

[2] H. Osborne, "Fossil Fuel and Land Use behind $\mathrm{CO}_{2}$ Rise," IPCC Report in Depth, The Guardian, February 2007. http://www.guardian.co.uk/science/2007/feb/02/greenpoli tics.climatechange

[3] B. Sugde, "On the Co-Operation of Government with Cane Growers on the Issue of Biofuel Production," Mpumalanga Cane Growers Association (MpCGA) Newsletter, Vol. 14, No. 7, 2007, 4 p.

http://www.sacanegrowers.co.za

[4] H. Youngs and C. Somerville, "Development of Feedstocks for Cellulosic Biofuels," F1000 Biol Reports, Vol. 4, No. 10, 2012, pp. 4-10.

[5] J. Hoogeven, J.-M. Faures and N. V. de Giessen, "Increased Biofuel Production in the Coming Decade: To What Extent Will It Affect Global Freshwater Resources?" Irrigation and Drainage, Vol. 58, 2009, pp. 148-160. doi:10.1002/ird.479

[6] AGES, "Hoedspruit Ethanol Plant: Water Specialist Assessment Report," 2008.

[7] Department of Water Affairs and Forestry, Internal Strategic Perspective, "Internal Strategic Perspective. Olifants Water Management Area," 2004.

[8] C. Bruwer, "The Riverine Ecosystems of the Kruger National Park," In: C. A. Bruwer, Ed., Proceedings of a Workshop on the Flow Requirements of Kruger National Park Rivers, 1991, p. 118.

[9] K. Rogers and R. Bestbier, "Development of a Protocol for the Definition of the Desired State of Riverine Systems in South Africa," Research Report Series, South African Wetlands Conservation Programme, Department of Environmental Affairs and Tourism, Pretoria, 1997, p. 100.

[10] T. K. Gyedu-Ababio, "Water Crisis in the Kruger National Park: A Position Paper," Conservation Management Department, Water Resources Section, Kruger National Park, 2005, p. 3.

[11] F. J. Venter, J. R. Naiman, C. H. Biggs and D. J. Pienaar, "The Evolution of Conservation Management Philosophy: Science, Environmental Change and Social Adjustments in Kruger National Park," Ecosystems, Vol. 11, No. 2, 2008, pp. 173-192. doi:10.1007/s10021-007-9116-x

[12] S. Varghese, "Biofuels and Global Water Challenges," Institute for Agriculture and Trade Policy, Minneapolis, 2007 , p. 7.

[13] D. Keeney and M. Muller, "Water Use by Ethanol Plants: Potential Challenges," Institute for Agriculture and Trade Policy, Minneapolis, 2008. http://www.agobservatory.org/library.cfm?refid=89449

[14] UNESCO IHE, "Biofuel Impacts on Water-What Do We Know, and What Do We Need," 2008. www.unesco-ihe.org/content/download/1953/.../pwp_bio fuels.pdf
[15] The Department of Water Affairs and Forestry, "The Production of Biodiesel in South Africa: A Position Statement," Internal Report, Sub-Directorate: Stream Flow Reduction, Directorate: Water Abstraction and Instream Use, Pretoria, 2007, p. 12.

[16] Bosch Projects, "Engineering, Sugar Equipment and Energy," 2006. www.boschprojects.com

[17] Department of Water Affairs, "Development of a Reconciliation Strategy for the Olifants River Water Supply System," Final Report No.: P WMA 04/B50/00/8310/15, 2012.

[18] The Infrastructure News, "Biofuel on the South African Horizon," 2012.

www.infrastructurene.ws/2012biofuel-on-the-south-africanhorizon

[19] Joint Nature Conservation Committee (JNCC), "Transport Biofuels and Biodiversity," Position Statement, Draft Report, 2007, p. 13. http://www.jncc.gov.uk/pdf/COMM_07

[20] United Nations Environment Programme (UNEP), “An Overview of Our Changing Environment," Division of Early Warning and Assessment (DEWA), United Nations Environment Programme, Nairobi, 2008.

[21] D. Keeney and C. Nanninga, "Biofuel and Global Biodiversity Institute for Agriculture and Trade Policy," Institute for Agriculture and Trade Policy, Minneapolis, 2008.

[22] M. J. Novacek and E. E. Cleland, "The Current Biodiversity Extinction Event: Scenarios for Mitigation and Recovery," Proceedings of National Academy of Science, Vol. 98, No. 10, 2001, pp. 5466-5470. doi:10.1073/pnas.091093698

[23] B. Wuethrich, "Reconstructing Brazil's Atlantic Rainforest," Science, Vol. 315, No. 5815, 2007, pp. 1070-1072. doi:10.1126/science.315.5815.1070

[24] Iracambi Research Centre, "The Atlantic Rainforest," 2008. http://www.iracambi.com/english/atlantic

[25] R. W. Malmsheimer, J. L. Bowyer, J. S. Fried, E. Gee, L. Izlar, R. A. Miner, I. A. Munn, E. Oneil and W. C. Stewart, "Managing Forests Because Carbon Matters: Integrating Energy, Products, and Land Management Policy," Journal of Forestry, Vol. 109, No. 7S, 2011, pp. S7-S50.

[26] C. L. Goodale, M. J. Apps, R. A. Birdsey, C. B. Field, L. S. Heath, R. A. Houghton, J. C. Jenkins, G. H. Kohlmaier, W. Kurz, S. Liu, G. J. Nabuurs, S. Nilsson and A. Z. Shvidenko, "Forest Carbon Sinks in the Northern Hemisphere," Ecological Applications, Vol. 12, No. 3, 2002. pp. 891-899.

doi:10.1890/1051-0761(2002)012[0891:FCSITN]2.0.CO;2

[27] The Science Daily, "Some Biofuels Are Worse Environmentally than Fossil Fuels," 2008.

http://www.sciencedaily.com/releases/2008/01/08010314 4404.htm

[28] E. A. Eniang, "Bio-Fuels: An Emerging Threat to Protected Areas?" A Letter to Peers in the Biodiversity Fraternity, Unpublished Letter to World Commission on Protected Areas, 2008, pp. 1-4.

[29] Parallax, "Prospects for Biodiesel in South Africa," 2007. www.parallaxonline.net/biofuel.html

[30] B. Tait, "Requirements and Viability for Biofuels in 
South Africa,” FSSA Journal, No. 2005, 2005, pp. 25-28.

[31] Terrestrial Ecosystems Research Initiative, "Liquid Biofuels for Transportation," India Country Study on Potential and Implications for Sustainable Agriculture and Energy, Funded by Bundesminiterium fur Enahrung Landwirtschaft und Verbraucherschutz, 2005.

www.gtz.de/de/dokumente/enbiofuels-for-transportation-inindia-2005

[32] R. Janssen, "Liquid Biofuels for Transportation in Tanza- nia: Potential and Implications for Sustainable Agriculture and Energy in the 21st Century," Bundesminiterium fur Enahrung Landwirtschaft und Verbraucherschutz, 2005. www.gtz.de/de/dokumente/en-biofuels-for-transportationintanzania-2005

[33] F. Dong, "Food Security and Biofuels Development: The Case of China," Iowa State University, Ames, 2007, pp. 1-18. 